\title{
PENGARUH EKSTRAK PROPOLIS TERHADAP EKSPRESI CASPASE 3, PROLIFERASI DAN INDUKSI APOPTOSIS PADA SEL KANKER KOLON (CELL LINE WiDr)
}

\author{
THE EFFECT OF PROPOLIS EXTRACT ON CASPASE 3 EXPRESSION, \\ PROLIFERATION AND INDUCTION OF APOPTOSIS ON CANCER COLONIAL CELL \\ (WiDr CELL LINE)
}

\author{
Esti Tantri Anandani, Paulus Kusnanto, Bambang Purwanto \\ Sub Bagian Gastro Entero Hepatologi, Bagian Ilmu Penyakit Dalam \\ FK UNS / RSUD Dr. Moewardi Surakarta \\ Korespondensi: dr. Esti Tantri Anandani, Sp. PD. Email: estitantri@gmail.com
}

\begin{abstract}
ABSTRAK
Kanker kolorektal mencapai sepuluh persen dari total tipe tumor di seluruh dunia dan merupakan kanker dengan mortalitas tertinggi di seluruh dunia. Kejadian kanker kolon terus meningkat seiring dengan pertambahan penduduk baik di negara berkembang maupun negara maju. Kemoterapi belum memberikan hasil yang optimal dan sering menimbulkan efek samping yang serius karena pada umumnya tidak bekerja spesifik pada sel kanker tetapi juga pada sel normal. Banyak bahan alam yang berpotensial untuk dikembangkan sebagai agen kombinasi seperti propolis, jinten, tapak dara, mengkudu, dan daun dewa. Propolis merupakan suplemen nutrisi yang dihasilkan oleh lebah dan telah digunakan sebagai pengobatan tradisional di dunia. Propolis sudah banyak dijadikan bahan penelitian karena aktivitas antibakteri, antijamur, antivirus dan hepatoprotektifnya. Propolis dan senyawa lainnya telah digunakan untuk mengobati inflamasi, untuk meningkatkan kekebalan tubuh, dan agen anti kanker. Penelitian bertujuan untuk melihat pengaruh pemberian propolis dari daerah Kerjo, Karanganyar, Indonesia terhadap ekspresi caspase 3, proliferasi dan induksi apoptosis pada kultur sel kanker kolon (cell line WiDr). Penelitian menggunakan desain eksperimental laboratorik dengan post test with control group design. Penelitian menggunakan kultur sel WiDr (sel kanker kolon) dengan pemberian ekstrak ethanol propolis (EEP). Pengamatan ekspresi caspase 3 dengan metode imunositokimia, sedangkan pengamatan proliferasi dengan metode doubling time dan induksi apoptosis dengan metode double staining. Hasil Penelitian didapatkan EEP dengan $\mathrm{IC}_{50}$ sebesar $140 \mu \mathrm{g} / \mathrm{mL}$ meningkatkan ekspresi caspase 3 sebesar 42,1\% dibandingkan kelompok kontrol 6,89\%. EEP meningkatkan ekspresi caspase 3 sebanding dengan peningkatan konsentrasi EEP. EEP dengan dosis konsentrasi $70,140,280 \mu \mathrm{g} / \mathrm{mL}$ mampu menekan proliferasi baik pada proliferasi jam ke-24, 48, maupun 72. EEP dengan IC50 sebesar $140 \mu \mathrm{g} / \mathrm{mL}$ meningkatkan induksi apoptosis sebesar 53,16\% dibandingkan kelompokkontrol 0,64\%. Pemberian EEP meningkatkan induksi apoptosis sebanding dengan peningkatan konsentrasi EEP. Penelitian ini menunjukkan bahwa EEP mempunyai sifat antiproliferasi dan mampu menginduksi apoptosis pada sel WiDr.
\end{abstract}

Kata kunci: EEP, caspase 3, proliferasi, apoptosis, WiDr

\section{ABSTRACT}

Colorectal cancer accounts for ten percent of all tumor types worldwide and is the highest mortality cancer worldwide. The incidence of colon cancer continues to increase along with population growth in both developing and developed countries. Chemotherapy has not given optimal results and often cause serious side effects because it generally does not work specifically on cancer cells but also in normal cells. Many natural materials that have the potential to be developed as a combination agent such as propolis, cumin, Madagascar periwinkle, great morinda, and daun dewa. Propolis is a nutritional supplement produced by bees and has been used as a traditional medicine in the world. Propolis has been widely used as a research material because of its antibacterial, antifungal, antiviral and hepatoprotective activity. Propolis and other compounds have been used to treat inflammation, to boost immunity, and anti-cancer agents. The aimed of this study was to assess the effects of ethanol extract of propolis (EEP) originating from Kerjo, Karanganyar, Indonesia on expression of caspase 3, proliferation and induction of apoptosis in colon adenocarcinoma cell culture (WiDr). This study was an experimental research laboratories, post-test with control group design. The study used cell culture of WiDr (colon cancer cells) with 
ethanol propolis extract (EEP) administration. Observation of caspase 3 expression with immunocytochemical method, while proliferation observation with doubling time method and induction of apoptosis by double staining method. The results obtained EEP with $I C_{50}$ of $140 \mu \mathrm{g} / \mathrm{mL}$ increased caspase 3 expression by $42.1 \%$ compared to the control group of $6.89 \%$. EEP increased caspase 3 expression in proportion to increase EEP concentrations. EEP with concentration doses of 70, 140,280 $\mathrm{g} / \mathrm{mL}$ were able to suppress proliferation either at 24,48 , and 72 hours of proliferation. EEP with IC50 of $140 \mu \mathrm{g} / \mathrm{mL}$ increased the apoptotic induction by $53.16 \%$ compared to the control group $0.64 \%$. Giving EEP increases apoptotic induction in proportion to increased EEP concentrations. This study showed that EEP has anti proliferative properties and was abled to induce apoptosis in WiDr cells.

Keywords: EEP, caspase 3, proliferation, apoptosis, WiDr

\section{PENDAHULUAN}

Kanker adalah suatu istilah untuk penyakit yang melibatkan pembelahan sel secara abnormal, tanpa kontrol dan dapat menyerang jaringan di sekitarnya. Sel kanker kehilangan sistem kontrol yang secara normal mencegah pertumbuhan sel yang berlebihan dan invasi sel ke jaringan yang lain. Kanker merupakan penyebab kematian utama, baik di negara maju maupun negara berkembang. Berdasarkan Global Cancer tahun 2012 di seluruh dunia terdapat sekitar 14,1 juta kasus baru dan 8,2 juta kematian akibat kanker (Globocan, 2013).

Kanker kolorektal atau kanker kolon adalah suatu bentuk keganasan yang terjadi pada daerah kolon, rektum, dan appendiks (usus buntu). Kanker kolorektal merupakan kanker ketiga terbanyak di seluruh dunia untuk pria dan kedua terbanyak untuk wanita, merupakan $10 \%$ dari total tipe tumor di seluruh dunia dan lebih dari 1 juta kasus setiap tahunnya. Angka kejadian kanker kolon terus meningkat seiring dengan pertambahan penduduk baik di negara berkembang maupun negara maju. Kanker kolorektal mengakibatkan 0,7 juta kematian pada tahun 2012 dan merupakan salah satu kanker dengan angka kematian tertinggi di seluruh dunia. Kanker kolon timbul melalui interaksi yang kompleks antara faktor genetik dan faktor lingkungan. Kanker kolon terjadi sebagai akibat dari kerusakan genetik pada lokus yang mengontrol pertumbuhan sel. Perubahan dari sel kolon normal menjadi jaringan adenomatosa dan akhirnya karsinoma kolon akibat dari mutasi yang mempercepat pertumbuhan sel. Terapi dasar kanker kolon adalah operasi, yaitu eksisi total. Namun sebagian besar pasien kanker kolon masih memerlukan terapi adjuvan. Adjuvan radiokemoterapi ini merupakan standar untuk pasien dengan kanker kolorektal stage II dan III. Neoadjuvan radiokemoterapi dicadangkan untuk kanker kolorektal yang sudah lanjut (uT4). Terapi dengan kemoterapi belum memberikan hasil yang optimal dan sering menimbulkan efek samping yang serius karena pada umumnya tidak bekerja spesifik pada sel kanker tetapi juga pada sel normal.

Strategi terapi kanker yang baru adalah dengan mengkombinasikan suatu senyawa kemopreventif yang bersifat tidak toksik dengan agen kemoterapi. Dengan mengkombinasikan agen kemoterapi dengan senyawa kemopreventif, diharapkan efikasi agen kemoterapi dapat meningkat karena adanya kombinasi yang sinergis dan memperkecil kemungkinan efek samping karena dosis agen kemoterapi menjadi berkurang.

Banyak bahan alam yang berpotensial untuk dikembangkan sebagai agen kombinasi seperti propolis, jinten, tapak dara, mengkudu, daun dewa. Propolis merupakan suplemen nutrisi yang dihasilkan oleh lebah dan telah digunakan sebagai pengobatan tradisional di dunia. Propolis atau lem lebah, adalah suatu zat yang dihasilkan lebah yang berasal dari resin yang didapatkannya dari pohon atau semak belukar dan serbuk sari, dikombinasikan dengan lilin dan sekresi kelenjar ludah lebah yang kaya akan enzim digunakan untuk proteksi sarang lebah. (Watanabe et al., 2011). Propolis sudah banyak dijadikan bahan penelitian karena aktivitas antibakteri, antijamur , antivirus dan hepatoprotektifnya. Propolis larut air, propolis larut alkohol, dan senyawa lainnya telah digunakan untuk mengobati inflamasi, untuk meningkatkan kekebalan tubuh, dan agen anti kanker. Propolis mempengaruhi protein pro apoptosis (Bax, Bak, caspase 3, cytochrome C), protein regulator diferensiasi sel (p38, p56, p21, cyclin dependent kinase) dan target yang berperan pada inflamasi yang terkait dengan kanker, seperti $N F \kappa B$ maupun cyclooxigenase two (Paulino et al., 2009).

Berdasarkan fakta-fakta yang telah diuraikan di atas, mendorong peneliti untuk mengetahui pengaruh pemberian propolis dari 
daerah Kerjo, Karanganyar, Indonesia terhadap ekspresi caspase 3, proliferasi dan apoptosis pada kultur sel WiDr (cell line kanker kolon). Penelitian ini sebagai upaya penemuan dan pengembangan strategi baru dalam terapi kanker dan kombinasi terapi, khususnya kanker kolon.

\section{METODE PENELITIAN}

Penelitian ini merupakan penelitian eksperimental laboratorik dengan menggunakan post test with control group design. Penelitian dilakukan pada kultur sel WiDr (sel kanker kolon) dengan pemberian propolis.

Pengamatan ekspresi caspase 3 dilakukan dengan metode imunositokimia, pengamatan proliferasi dengan metode doubling time, sedangkan pengamatan induksi apoptosis dilakukan dengan double staining.

\section{HASIL DAN PEMBAHASAN}

1. Uji sitotoksisitas dengan MTTassay untuk menetapkan nilai IC $_{50}$ ekstrak etanol propolis dan 5-Fluorouracil.

Sel $W i D r$ ditumbuhkan pada media komplit, selanjutnya diberikan perlakuan dengan ekstrak etanol propolis. Sel $W i D r$ yang hidup memiliki morfologi berbentuk poligonal dan menempel pada dasar sumuran, sedangkan sel WiDr yang mati bentuknya menjadi bulat dan lebih kecil dari sel hidup, tersebar dan tidak menempel pada dasar sumuran.

Data yang didapat dari uji sitotoksisitas dengan MTT assay berupa absorbansi dari tiap sumuran yang merupakan hasil pembacaan dengan menggunakan ELISA reader pada panjang gelombang $595 \mathrm{~nm}$. Untuk mendapatkan persentase viabilitas sel, data yang didapat tersebut kemudian diolah lebih lanjut dengan perhitungan cara yaitu membandingkan nilai absorbansi antara sel yang diberi perlakuan dan kontrol (sel tanpa perlakuan) setelah masing-masing dikurangi dengan kontrol media (blank). Data tersebut digunakan untuk menetapkan nilai $\mathrm{IC}_{50}$ bahan uji dengan menggunakan analisis regresi linear antara dosis bahan uji dan persentase viabilitas sel WiDr. Nilai rata-rata persentase viabilitas sel $\mathrm{WiDr}$ dan $\mathrm{IC}_{50}$ dari bahan uji ditunjukkan pada Tabel 1

Tabel 1. Peningkatan konsentrasi EEP menyebabkan penurunan persentase viabilitas sel WiDr. Pada konsentrasi EEP yang terendah $(12,5 \mu \mathrm{g} / \mathrm{mL})$, diperoleh persentase viabilitas sel WiDr yang tinggi $(126,6 \%)$. Pada konsentrasi EEP yang tertinggi $(200 \mu \mathrm{g} / \mathrm{mL})$, diperoleh persentase viabilitas sel WiDr yang terendah (15,31\%).

\begin{tabular}{cccc}
\hline Bahan Uji & $\begin{array}{c}\text { Konsentrasi } \\
(\boldsymbol{\mu g} / \mathbf{m L})\end{array}$ & $\begin{array}{c}\text { Rata-rata viabilitas sel } \mathbf{W i D r} \\
(\mathbf{\%} \pm \mathbf{S D})\end{array}$ & $\mathbf{I C}_{\mathbf{5 0}} \pm \mathbf{S D}(\boldsymbol{\mu g} / \mathbf{m L})$ \\
\hline Ekstrak & 12,5 & $126,60 \pm 7,92$ & \\
Etanol & 25 & $103,93 \pm 7,23$ & \\
Propolis & 50 & $67,78 \pm 1,63$ & $139,61 \pm 49,48$ \\
(EEP) & 100 & $34,48 \pm 2,10$ & \\
& 200 & $15,31 \pm 1,75$ & \\
& 12,5 & $118,57 \pm 5,57$ & $502,33 \pm 60,52$ \\
5-Fluorouracil & 25 & $114,17 \pm 3,83$ & \\
(5-FU) & 50 & $112,61 \pm 6,86$ & \\
& 100 & $105,37 \pm 3,09$ & \\
& 200 & $91,27 \pm 4,86$ & \\
\hline
\end{tabular}

Dari analisis regresi linear diperoleh nilai $\mathrm{IC}_{50}$ EEP sebesar 139,61 $\mu \mathrm{g} / \mathrm{mL}$. kemudian nilai $\mathrm{IC}_{50}$ EEP yang didapat ini digunakan sebagai dasar penentuan konsentrasi EEP pada uji selanjutnya, yaitu sebesar 70, 140, dan $280 \mu \mathrm{g} / \mathrm{mL}\left(1 / 2 \mathrm{IC}_{50}\right.$, $\mathrm{IC}_{50}$ dan $\left.2 \mathrm{IC}_{50}\right)$. Nilai $\mathrm{IC}_{50}$ 5-FU yaitu sebesar $502,33 \mu \mathrm{g} / \mathrm{mL}$ akan digunakan sebagai kontrol positif.

\section{Pengamatan ekspresi caspase 3}

Caspase 3 adalah family dari endoprotease yang mempunyai peran penting dalam mekanisme regulasi sel untuk mengontrol inflamasi dan program kematian sel. Aktivasi dari enzim caspase diatur dengan ketat dengan cara diproduksi sebagai enzim inaktif (procaspase), dimana mereka akan mengalami agregasi menuju dimer ato kompleks 
makromolekul dan menyebabkan aktivitas katalitik setelah mendapat signaling yang menyebabkan procaspase teraktivasi menjadi caspase. Untuk mengetahui apakah induksi apoptosis sel $\mathrm{WiDr}$ setelah pemberian EEP selama 24 jam terkait peningkatan ekspresi caspase 3, maka dilakukan pengamatan ekspresi caspase 3 pada sel $\mathrm{WiDr}$ dengan pengecatan imunositokimia. Pengecatan imunositokimia untuk ekspresi caspase 3 dilakukan pada 6 kelompok perlakuan (kontrol, EEP $1 / 2$ IC50,
EEP IC50, EEP 2IC50, 5FU IC50 dan kombinasi EEP 2IC50 dan 5FU IC50) dan masing-masing kelompok perlakuan tersebut dibuat duplicate.

Data yang diperoleh berupa persentase sel yang mengekspresikan caspase 3 (tampak sebagai warna coklat pada inti sel maupun sitoplasma) dari keseluruhan sel pada 6 lapangan pandang (Gambar 2). Penilaiannya dilakukan pada 2 slide dari tiaptiap kelompok perlakuan.

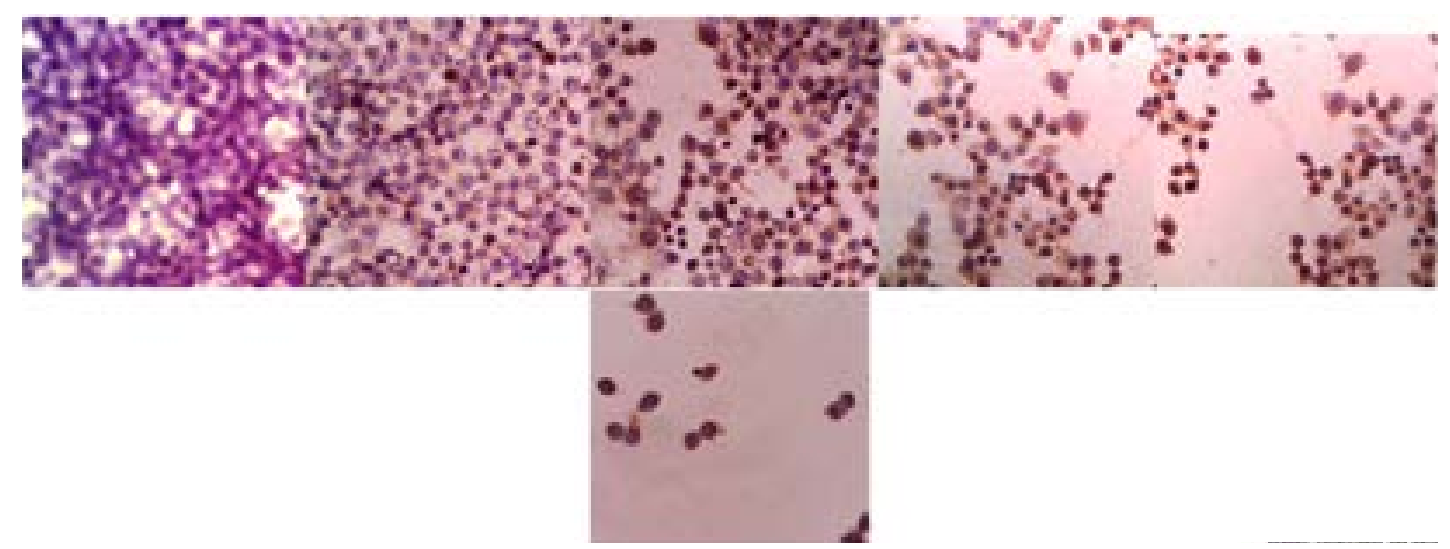

Gambar 1. Hasil pengecatan imunositokimia perbesaran 400 kali untuk ekspresi p21 pada sel WiDr setelah perlakuan dan inkubasi selama 24 jam pada kelompok control sel (a), kelompok dengan EEP konsentrasi $1 / 2$ IC50 (b), IC $_{50}$ (c), $2 \mathrm{IC}_{50}(\mathrm{~d})$, kelompok dengan 5-FU (e) dan kelompok kombinasi $\mathrm{IC}_{50} \mathrm{EEP}$ dan 5FU (f).

Tabel 1. .Hubungan antara konsentrasi bahan uji dengan rata-rata persentase ekspresi caspase 3 sel $W i D r$ setelah inkubasi 24 jam.

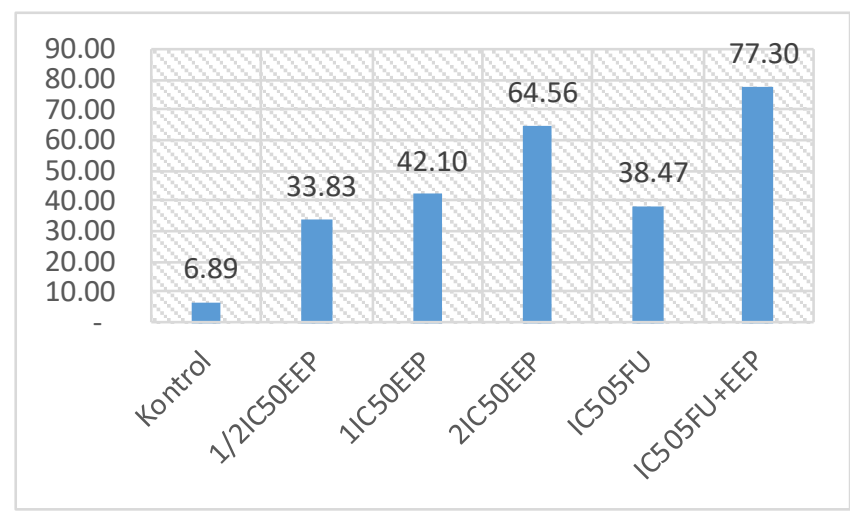

Dari grafik di atas, terlihat bahwa pemberian EEP dengan $\mathrm{IC}_{50}$ sebesar $140 \mu \mathrm{g} / \mathrm{mL}$ meningkatkan ekspresi caspase 3 sebesar 42,1\% dibandingkan kontrol 6,89\%. Pemberian EEP selama 24 jam meningkatkan ekspresi caspase 3 dimana peningkatan ekspresi caspase 3 sebanding dengan peningkatan konsentrasi EEP.

\section{Uji induksi apoptosis EEP pada sel WiDr dengan double staining}

Uji induksi apoptosis dilakukan untuk menilai EEP dalam menginduksi apoptosis pada sel WiDr. Pengujian dilakukan pada enam kelompok perlakuan, yaitu kelompok dengan EEP konsentrasi $70,140,280 \mu \mathrm{g} / \mathrm{mL}\left(1 / 2 \mathrm{IC}_{50} \mathrm{IC}_{50}\right.$, dan 2 
$\left.\mathrm{IC}_{50}\right)$, kelompok dengan 5-FU konsentrasi $500 \mu \mathrm{g} /$ $\mathrm{mL}\left(\mathrm{IC}_{50}\right)$, kelompok kombinasi EEP konsentrasi $140 \mu \mathrm{g} / \mathrm{mL}\left(\mathrm{IC}_{50}\right)$ dan $5 \mathrm{FU} 500 \mu \mathrm{g} / \mathrm{mL}\left(\mathrm{IC}_{50}\right)$, dan kelompok kontrol tanpa perlakuan.
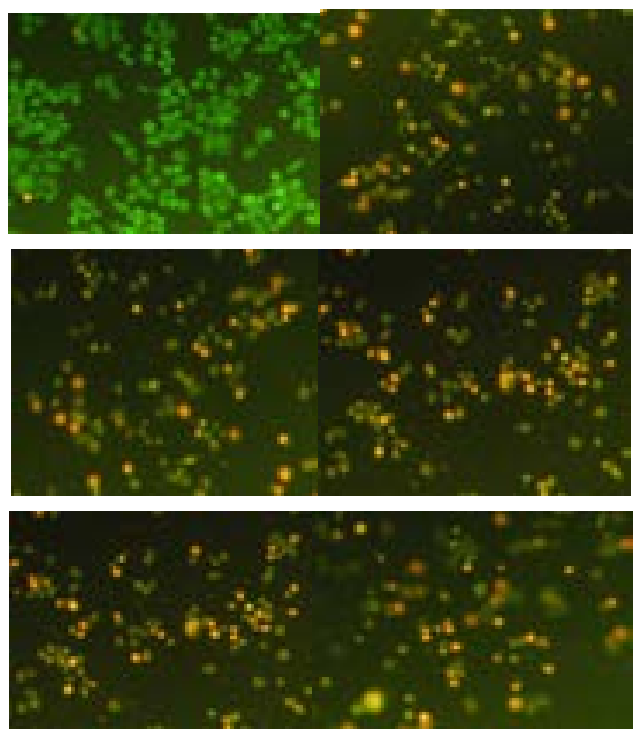

Gambar 2. Hasil pengecatan dengan metode double staining pada uji induksi apoptosis perbesaran 400 kali pada sel WiDr pada kelompok kontrol sel (a), kelompok dengan EEP konsentrasi $1 / 2 \operatorname{IC50}(\mathrm{b}), \mathrm{IC}_{50}(\mathrm{c}), 2 \mathrm{IC}_{50}(\mathrm{~d})$, kelompok dengan 5-FU (e) dan kelompok kombinasi IC I0 $_{50}$ EEP dan 5FU (f).

Tabel 2. .Hubungan antara konsentrasi bahan uji dengan rata-rata persentase induksi apoptosis sel WiDr setelah inkubasi 24 jam.

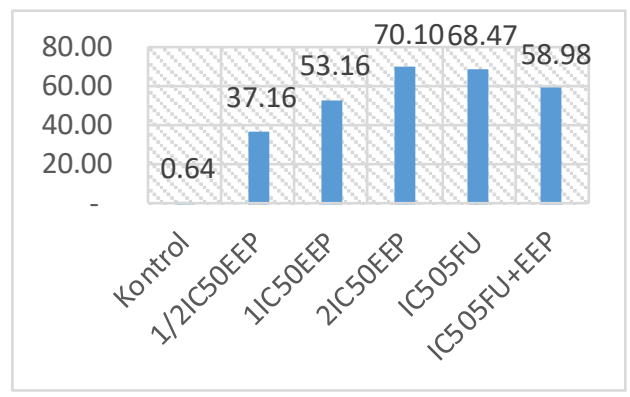

Dari grafik di atas, terlihat bahwa pemberian EEP selama 24 jam menyebabkan peningkatan induksi apoptosis dimana peningkatan induksi apoptosis sebanding dengan peningkatan konsentrasi EEP.

\section{Pengamatan proliferasi menggunakan doubling time}

Uji pengamatan proliferasi dilakukan untuk menilai EEP dalam menghambat proliferasi pada sel WiDr. Pengujian dilakukan pada enam kelompok perlakuan, yaitu kelompok dengan EEP konsentrasi 70, 140,280 $\mu \mathrm{g} / \mathrm{mL}\left(1 / 2 \mathrm{IC}_{50} \mathrm{IC}_{50}\right.$ dan 2 $\left.\mathrm{IC}_{50}\right)$, kelompok dengan 5-FU konsentrasi $500 \mu \mathrm{g} /$ $\mathrm{mL}\left(\mathrm{IC}_{50}\right)$, kelompok kombinasi EEP konsentrasi $140 \mu \mathrm{g} / \mathrm{mL}\left(\mathrm{IC}_{50}\right)$ dan $5 \mathrm{FU} 500 \mu \mathrm{g} / \mathrm{mL}\left(\mathrm{IC}_{50}\right)$, dan kelompok kontrol tanpa perlakuan dan dilakukan pada 3 waktu yang berbeda, yaitu 24 jam, 48 jam, dan 72 jam.

Tabel 3. .Hubungan antara konsentrasi bahan uji dengan proliferasisel $\mathrm{WiDr}$ pada 24 jam.

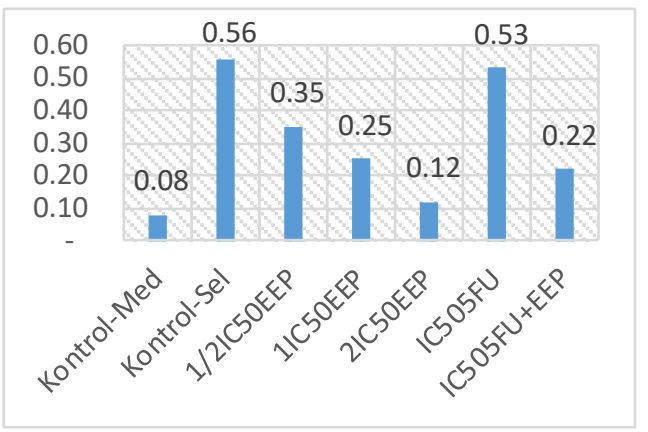

Tabel 4. .Hubungan antara konsentrasi bahan uji dengan proliferasisel $\mathrm{WiDr}$ pada 48 jam.

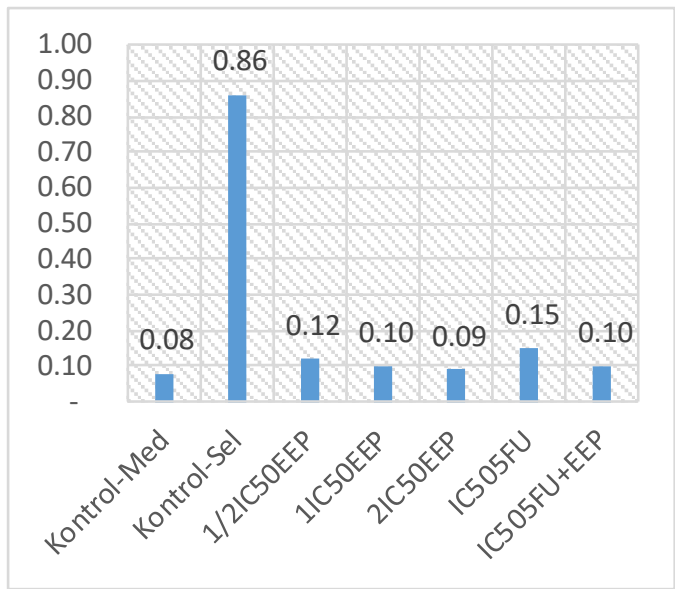


Tabel 5. .Hubungan antara konsentrasi bahan uji dengan proliferasisel WiDr pada 72 jam.

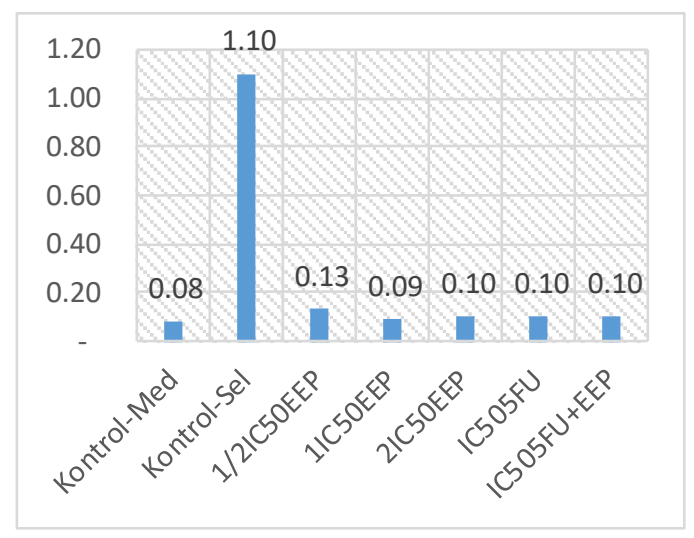

Pada proliferasi 24 jam, nilai rata-rata pada kelompok kontrol media hanya sebesar 0,08, jauh lebih rendah jika dibandingkan dengan ratarata pada kelompok kontrol sel yang besarnya mencapai 0,56. Hal itu menunjukkan bahwa walaupun dalam media terdapat proliferasi namun relatif sangat kecil. Setelah dilakukan pemberian perlakuan EEP maka rata-rata proliferasi pada $\mathrm{k}-1 / 2 \mathrm{IC}_{50}$ EEP lebih rendah yaitu mencapai 0,35, demikian pula pada k-1 $\mathrm{IC}_{50}$ EEP juga lebih rendah lagi yaitu mencapai 0,25 . Pada k-2 $\mathrm{IC}_{50}$ EEP ratarata proliferasi semakin rendah lagi yaitu mencapai 0,12 . Hal ini menunjukkan bahwa semakin tinggi dosis EEP diberikan ada kecenderungan semakin menurunkan rata-rata proliferasi.

Pada proliferasi 48 jam, proliferasi pada kelompok kontrol media hanya sebesar 0,08 lebih rendah jika dibandingkan dengan rata-rata pada kelompok kontrol sel yang besarnya mencapai 0,86 . Hal itu menunjukkan bahwa walaupun dalam media terdapat proliferasi namun relatif sangat kecil. Setelah dilakukan pemberian perlakuan EEP maka rata-rata proliferasi pada k-1/2 IC50 EEP lebih rendah yaitu mencapai 0,12 , demikian pula pada k-1 IC50 EEP juga lebih rendah lagi yaitu mencapai 0,10. Pada k-2 IC50 EEP rata-rata proliferasi semakin lebih rendah lagi yaitu menjadi sebesar 0,09 . Hal ini menunjukkan bahwa semakin tinggi dosis EEP diberikan ada kecenderungan semakin rendahnya rata-rata proliferasi.

Pada proliferasi 72 jam, proliferasi pada kelompok kontrol media hanya sebesar 0,08 lebih rendah jika dibandingkan dengan rata-rata pada kelompok kontrol-sel yang besarnya mencapai 1,10. Hal itu menunjukkan bahwa walaupun dalam media terdapat proliferasi namun relatif sangat kecil. Setelah dilakukan pemberian perlakuan EEP maka rata-rata proliferasi pada k-1/2 IC50 EEP jauh lebih rendah yaitu mencapai 0,13 , demikian pula pada k-1 IC50 EEP rata-rata proliferasi menjadi lebih rendah lagi yaitu mencapai 0,09 . Pada k-2 IC50 EEP rata-rata proliferasi lebih rendah sedikit atau jika dibulatkan sama yaitu mencapai 0,10 . Hal ini menunjukkan bahwa semakin tinggi dosis EEP diberikan tidak mesti berkecenderungan menurunkan rata-rata proliferasi secara terus menerus, pada dosis tertentu memang masih dapat menurunkan proliferasi tapi jika dibesarkan lagi justru menjadikan proliferasi dapat meningkat sedikit lebih tinggi lagi.

Penelitian ini dilakukan dengan melakukan pengujian sitotoksisitas senyawa ekstrak etanol propolis (EEP) pada sel WiDr menggunakan metode MTT assay untuk menetapkan nilai $\mathrm{IC}_{50}$ senyawa EEP yang selanjutnya akan digunakan sebagai dasar penetapan konsentrasi EEP untuk pengamatan ekspresi caspase 3, proliferasi maupun uji induksi apoptosis pada sel $\mathrm{WiDr}$ dan $\mathrm{IC}_{50}$ 5-fluorouracil (5-FU) sebagai kontrol.

Pada uji sitotoksisitas didapatkan bahwa persentase viabilitas sel $\mathrm{WiDr}$ semakin menurun sebanding dengan peningkatan konsentrasi EEP yang diberikan. Hasil uji sitotoksik ini sejalan dengan beberapa penelitian eksperimen in vitro yang pernah dilakukan sebelumnya, yang menyatakan bahwa EEP mempunyai efek sitotoksik yang kuat yang dapat menurunkan viabilitas dan pertumbuhan sel kanker gaster AGS dan EEP mampu menghambat pertumbuhan pada berbagai sel tumor karena pada propolis terdapat efek sitotoksik, antiproliferatif dan induksi apoptosis (Kubina et al, 2015).

Pada uji proliferasi menggunakan doubling time didapatkan bahwa baik pada proliferasi 24 jam, 48 jam maupun 72 jam didapatkan nilai proliferasi yang semakin rendah sejalan dengan peningkatan dosis EEP yang diberikan. Pada penelitian lainnya, Lie et al melaporkan bahwa propolis Brazil dan Belanda mempunyai aktivitas antiproliferasi pada kanker kolon murin 26-L5, murin B16-BL6 melanoma, human HT1080 fibrosarkoma, dan human A549 adenokarsinoma paru (Lie et al., 2007). Propolis Chili menghambat pertumbuhan human KB kanker epidermoid mulut dan DU145 androgen intensive prostate carcinoma 
cell line (Russo et al, 2004). Sawicka et al. 2009 melaporkan bahwa komponen propolis dapat menghambat proliferasi sel atau menginduksi apoptosis dengan cara menekan kompleks siklin, meningkatkan kadar cyclin-dependent kinase (CDK) inhibitor seperti p16, p21, siklus sel, aktivasi Bax, p53 dan p21, p38MAPK, JNK, ERK kinase, melepas sitokrom $\mathrm{C}$ ke sitosol dan mengaktivasi caspase pada sel tumor (Sawicka et al.2009)

Pada penelitian ini didapatkan bahwa ekspresi caspase 3 meningkat sejalan dengan peningkatan dosis EEP yang digunakan, dimana pada pemberian EEP dosis $1 / 2 \mathrm{IC}_{50}(70 \mu \mathrm{g} / \mathrm{mL})$ didapatkan peningkatan ekspresi caspase $33,83 \%$ jika dibandingkan kelompok control sel yang hanya $6,89 \%$. Begitu juga pada dosis $1 \mathrm{IC}_{50}$ dan $2 \mathrm{IC}_{50}$ didapatkan peningkatan caspase 3 . Hal ini sejalan dengan uji induksi apoptosis yang kami lakukan, dimana pemberian EEP dengan dengan konsentrasi $1 / 2 \mathrm{IC}_{50}$ mampu menginduksi apoptosis sel $\mathrm{WiDr}$ sebesar 37,16\%. Dan peningkatan dosis EEP menjadi $1 \mathrm{IC}_{50}$ dan $2 \mathrm{IC}_{50}$ meningkatkan induksi apoptosis menjadi $53,16 \%$ dan $70,1 \%$. Hal ini sesuai dengan beberapa penelitian yang telah dilakukan sebelumnya. Lee et al, melaporkan bahwa propolis memiliki aktivitas sitotoksik dan akan menginduksi pengeluaran cytochrome c dari mitokondria ke sitosol dan mengaktifkan caspase 3 sehingga dapat memicu apoptosis (Lee et al, 2003). Szliszka et al. melaporkan bahwa EEP mempunyai efek proapoptosis pada sel kanker HeLa, dimana pada penelitian tersebut didapatkan bahwa penghambatan pertumbuhan dan induksi apoptosis pada sel kanker HeLa berhubungan dengan dosis EEP yang diberikan (Szliszka et al., 2009).

\section{SIMPULAN}

1. Ada pengaruh pemberian ekstrak propolis terhadap peningkatan ekspresi caspase 3 pada kultur sel WiDr.

2. Ada pengaruh pemberian ekstrak propolis terhadap proliferasi pada kultur sel WiDr.

3. Ada pengaruh pemberian ekstrak propolis terhadap induksi apoptosis pada kultur sel WiDr.

\section{DAFTAR PUSTAKA}

Globocan. 2013. Cancer Fact Sheets for Colorectal Cancer.2013. Available from: URL: http://globocan. iarc.fr/Pages/fact_sheets_cancer.aspx

Kubina, R., Dzik, A.K., Dziedzic, A., Bielec, B., Wojtczka, R.D., Buldok, R.J., Wysznynska, M., et al. 2015. The ethanol extract of polish propolis exhibits anti-proliferative and/or pro-apoptotic effect on HCT 116 colon cancer and Me45 malignant melanoma cell in vitro conditions. Adv Clin Exp Med. 24(2): 203-212.

Lee YJ, Kuo HC, Chu CY, Wang CJ, Lin WC, Tseng TH, 2003.Involvement of tumor suppressor protein p53 and p38 MAPK in caffeic acid phenethyl ester-induced apoptosis of C6 glioma cells. Biochem Pharmacol. 66, 2281-2289Lie, H., Kapur, A., Yang, J.X., Srivastava, S., McLeod, D.G., Paredes-Guzman, J.F et al. 2007. Antiproliferation of human prostat cancer cell by ethanolic extracts of Brasilian propolis and its botanical origin. Int J Oncol; 31:601-06.

Paulino, N., Abreu, S.R.L., Machodo, G., Silveira, E. 2009. Scientific evidences to pharmacological anticancer action of Baccharis dracunculifolia Brazilian propolis. Rev Pesq Inov Farm. 1(1): 15-26.

Russo A, Cardile V, Sanchez F, Troncoso N, Vanella A, Garbarino J. 2004. Chillean propolis : antioxidant activity and antiproliferative action in human tumor cell lines. Life Scie; 76(5): 545-58.

Russo, M.W., Wei, J.T., Thiny, M.T., et al. 2004. Digestive and liver diseases statistics. Gastroenterology.126:1448-53.

Sawicka D, Car H, Borawska MH, Niklinski J. 2012. The anticancer activity of propolis. Drugs. 50(1): 25-37.

Szliszka E, czuba ZP, Domino M, Mazur B, Zydowicz G, Krol W. 2009. Ethanolic extract of propolis (EEP) enhances the apoptosis-inducing potential of TRAIL in cancer cells. Molecules. 14: 
738-754.

Watanabe, M.A.E., Amarante, M.K., Conti, B.J., Sforcin, J.M. 2011. Cytotoxic constituents of propolis inducing anticancer effect: a review. JPP. 63: 1378-1386. 